\title{
Policies, Practices of Teacher Education Institutions and the Performance of their Graduates
}

\author{
Dr. Norman V. Alfonso
}

\begin{abstract}
The research study is about Policies, Practices of Teacher Education Institutions (TEIs) in the province of Nueva Ecija, Philippines and the Performance of their Graduates in the Licensure Examination for Teachers (LET). The respondents are deans/head, teachers, and teacher education graduates or passers of the 12 respondent TEIs. The study was conducted within the first semester of the Academic Year 2018-2019. Descriptive research design was used in the study with quantitative and qualitative method. The 12 TEIs were identified through purposive sampling technique while the teachers and education graduates were thru simple random sampling. Questionnaires and interview guide were utilized as the main data gathering instruments. Based on the findings of the study, the following were drawn conclusions: TEIs are cognizant that admission, retention, and LET preparation policies are important academic guidelines or procedures. Equally, TEIs are mindful that academic policies are vital means to establish and maintain quality instruction to BEEd students; Most TEIs failed to address their academic problems considering that their BEEd LET results were below the national passing rate during 10 consecutive examinations from years 2013-2017. Also, the Commission on Higher Education failed to observe or impose its policies concerning the persistent below national passing rate performance of TEIs in BEEd LET. TEIs' admission, retention, and LET preparation policies are big contributory factors towards a healthier LET performance for BEEd; and TEIs recognize the importance of achieving BEEd LET result that is above the national passing rate through the various practices they implement. Similarly, TEIs are aware of the possible legal and business consequences in case they failed in every examination. Lastly, TEIs are mindful that LET performance of their graduates is a measure or indicator of quality academic practices and processes. Based on the conclusions of the study, the following are the recommendations: Implementation of Academic Policies, Creation of Distinct
\end{abstract}

Academic Policies, Regular Revisiting of Curricula, and Institutionalization of LET Preparation Programs.

Keywords- Performance, policies, practices, teacher education.

\section{INTRODUCTION}

Education is a universal necessity; it is man's weapon towards a brighter future and surely a potent shield against ignorance through the significant direction and assistance of professional teachers. In one of the speeches of the incumbent Philippine President, Rodrigo Roa Duterte, he stressed that "Education is the single most important legacy that we can bestow upon our youth. It opens doors for countless opportunities that will lead to their further empowerment, greater success and the realization of their individual aspirations"[1]. Also, Nelson Mandela said, "Education is the most powerful weapon which you can use to change the world"[2].

To achieve the aforesaid perspective, the endowment of education in the country (Philippines), as well as the teaching profession, should be standardized but progressive and responsive in order to meet the challenges of the present and the future.Hence,the Commission on Higher Education (CHED) issued CHED Memorandum Order (CMO) No. 30 series of 2004[3] entitled "Revised Policies and Standards for Undergraduate Teacher Education Curriculum.'The Order particularly sets among others, the following: program specification, competency standards, curriculum and course specifications.

The quality of education by schools in the countryis being gauged based on the performance of graduates in the licensure examination for board courses like the Bachelor of Elementary Education (BEEd) which is known as the Licensure Examination for Teachers (LET). The LET is a written assessment required to all professional teacher applicants as mandated by Republic Act (RA) 7836 also known as the Teacher Professionalization Act of 1994.Hence, to become a qualified, professional and licensed teacher,one should pass the LET administered by 
the Professional Regulation Commission (PRC) governed by Republic Act 8981 also known as PRC Modernization Act of 2000.The authors in [4] underscored in their study that the licensure test is one of the factors that influence the overall quality of teacher effectiveness. Similarly, graduates' performance in the licensure examination reflects the quality of education and training provided by their schools [5].

Admission and retention policies of TEIs are means to control and standardize the delivery of quality education to students. According to [6] the quality of university education is determined to a considerable extent by the abilities of those it admits and retains, and there is widespread agreement that success in university education is strongly related to pre-university academic preparation and achievement of students. The researchers in [7] revealed in their study that admission policy predicts academic performance. The study of [8] found out that admission has a significant favorable influence on board examination performance. The study of [9]showed that Teacher Education Institutions perform better in LET due to selective access of students to a teacher education curriculu m. Also, [10] recommended that a serious retention policy/strict measure on who can continue in the BEEd program must be institutionalized.

Teachers and TEIs are gauged by their stakeholders and clienteles based on their performance in the licensure examination for board courses. According to [11], most countries worldwide require teachers to pass the mandated licensure examination before they are considered "highly qualified" and eligible for employ ment as teachers and be conferred the title of being a professional teacher. In the study of [12], they concluded that teacher licensure matters in the implementation of the basic education reform in the Philippine Education system. Relative to it, the Department of Budget and Management-Commission on Higher Education (DBM-CHEd) in 2004, as mentioned by [10] stated that LET Performance is one of the output indicators in the Normative Financing Scheme in determining the financial allocations given to State Universities and Colleges. Also, the study of [5] argued that graduates' performance in the licensure examination reflects the quality of education and training provided by their schools. As a reward to it, [12] stressed that a high percentage of LET passers contributes significantly to the accreditation of education programs of a specific college or university. Besides, it adds zest within the vicinity of school academe; it is one of the many reasons why schools offering education courses crave for a high percentage of LET passers. However, [13] dated July 16, 2012states that all universities and colleges offering teacher education program are ordered not just to pass but to maintain a standard, and that the obtained mean score in the LET must be higher than the national passing percentage rate or else they have to abide by the Teacher Educational Institution (TEI) recommendation to close down programs of TEI that consistently performed poorly for five years.

Hence, in connection thereto, the researcher conducted the study in order to examine the policies, practices of selected TEIs in Nueva Ecija and the BEEd LET performance of their graduates to ascertain the present situation of colleges and universities in the Province of Nueva Ecija and somehow suggest improvements for the benefit of TEIs and future professionalteachers.

The output of the study could somehow provide significant findings, conclusions, and recommendations that would be helpful to TEIs specifically on revisiting, developing, and improving their policies and practices for BEEd students or graduates. For this reason, LET rating of TEIs in the Province of Nueva Ecija could turn into satisfactory performance through consideration of this study.

Though pertinent studies are limited, various factors may affect teacher graduates' licensure examinationresult. However, it is proven that putting into practice the related academic school policies, appropriate curriculum, quality of instruction, academic performance, LET preparation, and school practices are, in some way, contributed to the improvement of TEIs in terms of LET performance for BEEd.

The study, then, presented the following specific problems, to wit:

1. What policies do the respondent schools offering teacher-education courses have on admission and retention?

2. What is the performance of the teacher education graduates from respondent schools in the BEEd LET?

3. How do the policies and practices of the TEls relate to the performance of their graduates?

4. Is there a significant relationship on the schools' policies in terms of admission and retention in the performance of education graduates in their BEEd LET?

Hypothesis

There is no significant relationship on the schools' policies (admission and retention) and the performance of education graduates in the LET. 


\section{METHODOLOGY}

The descriptive (quantitative and qualitative) research design was used in the study. As cited by [14], [15], said that descriptive method is a purposive process of gathering, analyzing, classifying, and tabulating data about prevailing conditions, practices, beliefs, processes, trends and cause-effect relationships and then making adequate and accurate interpretation about such data with or without the aid of the statistical methods. Also, as mentioned by [16],Kumar (2014) said that descriptive method can systematically describe a situation, problem, phenomenon, service or programs, or provides information or describes the attitude towards an is sue. Similarly, descriptive research design helps to provide answers to the questions of who, when, where, what and how associated with a particular research problem. Descriptive research is all about describing the people who take part in the research/study [17].

The study was conducted in the four congressional districts (CDs) of Nueva Ecija where the respondent TEIs were located. The locale of the study showed the specific area of location of respondent TEls. Also, the aforesaid figure clearly showed that there were twelve (12) respondent schools in the study comprising eight (8 or $66.67 \%$ ) colleges and four (4 or 33.33\%) universities. Also, three (3 or $25 \%$ ) of the respondent TEIs are public schools and nine (9 or $75 \%$ ) are private institutions.

The 12 respondents TEIs of the study were identified through purposive sampling technique. Teachers, LET passers or education graduates as respondents were identified through simple random sampling. The documentary analysis method gathered data on the performance level of the education graduates in the LET. Performance of the LET takers from 2013 to 2017 were taken from the website of the Professional Regulatory Commission (PRC) and validated with the record of each TEI. A survey was made to each TEI using the questionnaire. Focus group discussion (FGD) was also conducted to teacher education faculty members and graduates to shed light on is sues needing clarification and elaboration.

The content validity of the questionnaire was subjected to the analysis of experts. For clarity of the items and direction, the instruments were "tried out" to respondents in non-participating TEls whose characteristics are similar to the intended respondents. The interview guide was used to gather additional data when necessary and was also used to determine consistency of responses. Prior to data gathering, permission to gather the needed data was sought from schoolheads or authorized representatives.

\section{Data Analysis Techniques}

1. The policies of respondent TEIs were described using the following descriptors:

On admission, the students' admission policy was categorically described as selective and non-selective. The admission policies of first-year students, transferees, married, foreign students, and grade point average were enumerated and explained.

Retention policy, the retention policy was also categorized as selective and non-selective. The provisions were cited when teacher education students may continue their programs or when the admission to the program has already been terminated.

2. The performance level of teacher education graduates from 2013 to 2017 was described using the descriptors shown in Table 1.

Table.1: Descriptors on the LET Performance of BEEd

\begin{tabular}{cl}
\hline $\begin{array}{c}\text { Performance } \\
\text { Level }\end{array}$ & \multicolumn{1}{c}{ Verbal Description } \\
\hline Below NPR & $\begin{array}{l}\text {-Total percentage from first takers and repeaters fall } \\
\text { below the National Passing Percentage. } \\
\text {-Total percentage result from first takers and repeaters } \\
\text { Within NPR }\end{array}$ \\
above NPR & $\begin{array}{l}\text {-Total percentage from first takers and repeaters are } \\
\text { above the National Passing Percentage. }\end{array}$ \\
\hline
\end{tabular}

3. The relationship of the TEIs policies on admission, retention, and board examination preparation to the teacher-graduates' performance in the LET was determined using chi-square test. The IBM-SPSS software Version 16 was used in the statistical analysis.

4. The practices of the respondent schools implemented in ensuring the success of their graduates in the LET were enumerated and explained.

\section{RESULTS AND DISCUSSIONS}

1. Policies of Teacher Education Institutions on Students' Admission and Retention.

\subsection{On Students' Admission}

The 12 TEIs have admission policy in admitting teacher education applicants in the elementary and 
secondary education programs. The policy is selective or non- selective.

\section{a. First Year Students}

Four TEIs observe the "selective admission policy." They conduct entrance examination for incoming first year teacher education students, and only those who passed the entrance examination are qualified for admission. In public TEIs, the maximum number of students to be admitted is based on the quota. Application forms are provided with a minimal fee and should be accomplished/filled out honestly and completely before allowing the applicant to take the entrance examination.

Eight (8) TEIs implement a "nonselective" admission policy or otherwise known as "open admission policy" to first year teacher education students. In other words, no entrance examination is required among the first-year students seeking admission in their teachereducation programs.

The 12 TEIs (public or private) require all incoming teacher education students to present the following documents before admission: a) High School Report Card (Form 138), b) Certificate of good moral character, c) Photocopy of birth certificate, and d) Permanent Record (Form 137) and copies of picture.

\section{b. For Transferee - teacher Education Students}

All the 12 TEIs have an admission policy applicable for transferees. In common, the documents essential to TEIs are: a) Official Transcript of Records or Certification of Grades to be evaluated by the registration adviser, b) Honorable Dismissal, c) Photocopy of Birth Certificate, and d) copies of ID picture.

\section{c. For Married First Year Students}

Married students are being required by the 12 TEIs to submit the following: a) Certified copy of authenticated Marriage Certificate or photocopy from Philippine Statistics Office (PSO), and b) those require ments attached for incoming freshmen (if incoming $1^{\text {st }}$ year) or transferees (if a student is a transferee).

\section{d. For Foreign Students}

In this aspect, only six (6) of the TEIs were found to have admission policy for foreign students based on the TEIs' manuals. Documents required by TEIs are the following: a) Permit to study and placement from Commission on Higher Education (CHED), b) Photocopy of the Alien Certification of Registration (ACR), c) Photocopy of Birth Certificate, and d) copies of ID picture.

\section{e. Grade Point Average}

Students seeking admission in public TEIs must suffice the grade point average (GPA) of 85 or higher. One private TEI requires 84 or higher GPA.

The other TEIs do not strictly implement GPA as a requirement for admission, but close monitoring of the students' academic performance is being done every semester to make sure that the students may achieve the university academic requirement. A personal interview for the applicant is set for possible admission.

Enrollees are required to take a standardized test and passed it within the prescribed percentage score or rating. Passing the examination serve as a leeway for the applicant as an entrance passage in the program. Failure means barred from entering the desired program to pass the admission examination. Other requirements will follow before formally enrolling upon admission of the applicant.

The findings imply that TEIs know the vital role of admission policy to teacher education students. Further, it reinforced various researches which revealed that admission policy is important and must be practiced by TEIs as a formal and regular academic process for the benefit of the students. The result of the study is in congruence to a series of academic researches. [6]mentioned that the quality of university education is determined to a considerable extent by the abilities of those it admits and retains, and there is widespread agreement that success in university education is strongly related to pre-university academic preparation and achievement of students. In the same fashion, [9] stated that LET performance is predicted by three (3) aspects: the admission and retention policy, curriculum and instruction, and faculty competence. His study showed that in order for a TEI to perform better in the LET, it must 
begin with the selective [18] admission of students to a teacher education curriculum.Also, the study of revealed that Philippine Normal University Admission Test and College GPA are good predictors of graduates' performance in the licensure examination for teachers. Hence, the researcher recommended that strict compliance of conducting entrance examination should be given importance by the university. By the same token, [19] found out in their study that Admission Test, Degree Course, English Proficiency and Institutional Passing Rate of Education Graduates are the factors affecting [with] the effectiveness of education respondents in Licensure Examination for Teachers.Lastly, the authors in [20], as cited by [10], found out that college (GPA, Otis-Lennon School Ability Test (OLSAT) rating and English placement test passing were found to significantly affect performance in LET.

\subsection{On Students' Retention}

The 12 TEIs, based on their manuals, were found to have a common stand; that is, they have a retention policy (either selective or nonselective) but differ as some point and extent of implementation.

\section{a. For Public and Private TEIs}

Public and Private TEIs have the "3 subjects' rule" policy on retention which is called as "selective retention." The Rule states that should a student failed three (3) of his/her professional subjects in one semester, he/she would be "dismissed" or kicked-out in the college. Similarly, both group of TEIs reduce the enrolled subjects of student for the subsequent semester in case he/she failed two (2) of his/her professional subjects. For one (1) failed professional subject, a warning is given by the head of the program to the student.

\section{b. Implementation of Retention Policy}

The 12 TEIs differ in the implementation of their respective retention policy. In the case of public TEIs, based on the interviews with heads and teachers, they are strict in implementing their retention policy. According to the teachers, they merely follow the policy on retention provided in the student manual.In fact, listed names of kickedout teacher education students were shown by the college of education dean of one of the TEIs during the personal interview.

Also, for private TEIs, implementation of a retention policy is not firm. Interview with the deans and teachers admitted that they cannot just easily kick their students out practically because they magnified that without or limited students would result in retrenchment or no employment on their part. Interview and discussion with students and teachers revealed that the retention policy remains in the student manual without implementing at all.In addition, three (3) of the deans admitted that for series of times, they talked with their teachers to minimizegiving students of failing grades, instead they encouraged their teachers to conduct remedial measures for the benefit of their students. Henceforth, the interview results alone correctly justify how retention policy in private TEIs is being implemented.

Hereafter, being confronted with the above-cited facts, deans/heads and teachers of teacher education institutions understand clearly the worth of implementing retention policies whether private or public TEIs. However, in the case of public TEIs, it was easy or they are firm in the implementation of retention policies due to numerous numbers of enrolees caused by lower tuition fees (now free tuition) as compared with private TEIs. Private TEIs, however, cannot impose in the maximum level their retention policies due to their fear of losing their students.

\section{c. Goal of Retention}

All TEIs in terms of the intention of having a retention policy, though not expressed in the manual, is to impose or observe the delivery of quality education for teacher education students. Likewise, retention would improve the performance of teacher education in the Licensure Examination for Teachers. Consistently, all deans and teachers agreed that other than quality instruction, competent teachers, and great school administrators, proper imple mentation of academic policies such as retention is significant to the attainment of excellent licensure examination performance.The result of the study clearly suggests that deans/heads and teachers of TEIs recognize the value and relationship of retention policy towards quality education and LET 
performance. In connection thereto, [10] recommended in her study that a serious retention policy/strict measure on who can continue in the BSEd and BEEd programs must be institutionalized.

\section{Performance of Teacher Education Graduates from Respondent Teacher Education Institutions in the BEEdLET}

\subsection{LET Performance of Bachelor in Elementary Education}

Table 3 presents the national passing percentage in the BEEd-LET in Five Years and Performance Level of the TEI Graduates.

\section{a. For March and September 2013}

It can be gleaned that, in March, among the 12 TEIs five (5) TEIs (41.67\%) got an above performance while seven (7) TEIs (58.33\%) had below performance against the 27.7 NPP. The highest passing percentage performance was recorded as $60.94 \%(39 / 64)$ by TEI 2 , followed by TEI 9 with $50.82 \%$ (31/61). The lowest passing percentage was $6.00 \%(3 / 50)$ by TEI 3 described as below performance.

In September, four (4) TEIs $(33.33 \%)$ out of 12 TEIs had an above passing percentage while eight (8) TEIs (66.67\%) performed below against the 31.18 NPP. The highest was $56.52 \%(78 / 138)$ by TEI 2 , followed by $50.70 \%(36 / 71)$ and $50.00 \%(2 / 4)$ by TEIs 6 and 8 , respectively. TEIs 10 and 12 got $0.00 \%$ $(0 / 25 ; 0 / 49)$ described as below performance.

\section{b. For January and August 2014}

Both months of examination revealed that four (4) TEIs (33.33\%) out of 12 TEIs performed in the above while eight (8) TEIs $(66.67 \%)$ had below performance against the 29.89 and 35.74 NPPs. TEI 2 got the highest rank for January and August examinations with $60.00 \% \quad(48 / 80)$ and $52.03 \%(77 / 148)$ passing percentage. TEI 8 got the lowest in January with $0.00 \%(0 / 1)$ while TEI 12 had 2.67\% (2/75), the lowest in August with below performance description.

\section{c. For March and September 2015}

Both months of examination showed that four (4) TEIs (33.33\%) out of 12 TEIs performed in the above level while eight (8) TEIs (66.67\%) got below performance against the $27.7 \%$ and $31.36 \%$ NPP, respectively. TEI 8 got the highest with $100 \%$ (1/1) passing rate, TEI 9 with $50.39 \%$ (12/127), TEI 2 got $48.10 \%$ (38/79), and TEI 6 had a $39.47 \%(15 / 38)$ all with above performance description.

TEI 2 got the highest percentage in September with 52.94\% (63/119) followed by TEI 6 with $46.46 \%$ (37/80), and TEI 9 with $45.75 \%$ (97/212) all described as above performance. The lowest so far is TEI 8 with $0.00 \%(0 / 3)$ described as below performance.

\section{d. For March and September 2016}

There seems to be a quite improvement in term of the performance of TEIs. TEIs performed better with $5(41.67 \%)$ and six (6) TEIs (50\%) out of 12 TEIs got an above level performance while seven (7) TEIs (58.33\%) and six (6) TEIs (50\%) for the month of March and September performed below against 28.38 and $30.18 \mathrm{NPP}$, in order. TEI 9 got the highest percentage among the 12 TEIs with $56.63 \%$ (94/166) while TEI 8 got the highest with $100 \%$ (4/4) all described as above performance for the month of March and September, respectively. The lowest was TEI 8 with $0.00 \%(0 / 1)$ TEI 12 with $10 \%(5 / 50)$ passing rate described as below performance.

\section{e. For March and September 2017}

Both months of examination had a five (5) TEIs (41.67\%) out of 12 TEIs described as above performance while seven (7) TEIs (58.63\%) had below performance against $10.39 \%$ and $26.33 \%$ NPPs for the months of March and September, respectively. In March, the highest was $28.89 \%(26 / 90)$ by TEI 2 followed by TEI 9 $28.49 \%(53 / 186)$ described as above performance while TEIs 8 and 10 got the lowest with $0.00 \%$ $(0 / 2 ; 0 / 18)$ described as below performance.

In September, TEI 2 was the highest with $59.35 \%$ (92.155) followed by TEI 6 with $52.69 \%$ (49/63) describe as above performance while TEI 10 with $0.00 \%(0 / 26)$ described as below performance.

f. On the Overall Performance 
Table 3 clearly showed that TEIs 2,6 , and $9(3 / 12)$ were consistent in their BEEd LET performance since they all had an above performance on the 10 examinations from years 2013-2017. It means that three (3) TEIs' BEEd results were always above the National Passing Percentage while nine (9) TEIs (75\%) were inconsistent in their LET performance. TEIs 7 and 8 had a $60.00 \%(6 / 10)$, TEI 4 had a $20.00 \%(2 / 10)$, and TEIs 1 and 12 had $10.00 \%$ (1/10) LET results. However, TEIs 3, 5, 10, and 11 had never been in the above NPP performance during the 10 licensure examinations.

On the overall view, the BEEd LET performance could be described as alarming considering that among the 12 TEIs, seven (7) TEIs (58.33\%) made it in the below NPP performance. Miserably, four (4) TEIs garnered a zero total which means that they have never achieved an above the NPP performance. However, among the 12 TEIs, five (5) TEIs (41.67\%) performed above NPP performance. It signifies that, though it is hard to admit, there is a failure of education on the part of the TEls that could be attributed to various factors.

Based on interviews and discussions with the respondents, the discipline and consistency of implementing educational programs and policies, interventions, periodic assessment and evaluation, motivation of education graduates, adapting the current enhancement programs, appropriate curriculum, and preparation of education graduates in passing the LET are the factors they mentioned that could affect the quality of education they provide to their students.

Hence, it is safe to infer that the aforesaid seven (7) TEIs with below NPP performances did not observe their respective policies, curriculum enhancement, no academic interventions were done, no or little preparation was given to their students and those mentioned. Notably, the seven (7) TEIs are private institutions while the three (3) TEIs are public schools. The result of the study is quite related to the study of [21] which showed that student teachers experienced lack of educational training, shortages of resources, engaging with traditional teaching interventions and loss of global competency to achieve passing board examination are the problems encountered by the institution providing quality performances for a licensure examination. Also, [22] said that the effectiveness of a curriculum is measured using the results of the licensure examination. Schools usually develop remedial measures to increase the number of passers. Similarly, according to [23], curriculum misalignment including failure to fulfill educational pieces of training and mock examinations were the problems encountered by the education graduates.

Hence, TEIs who strictly implement academic school policies perform far better in terms of performance in the LET than those who do not.

Table.3: LET Results of BEEd from AY 2013-2017

\begin{tabular}{|c|c|c|c|c|c|c|c|c|c|c|c|c|c|c|c|}
\hline TEIs & \multicolumn{3}{|c|}{$\begin{array}{c}\text { MARCH, } 2013 \\
\text { NPP-27.70\% }\end{array}$} & \multicolumn{3}{|c|}{$\begin{array}{c}\text { SEPTEMBER, } 2013 \\
\text { NPP-31.18\% }\end{array}$} & \multicolumn{3}{|c|}{$\begin{array}{c}\text { JANUARY, } 2014 \\
\text { NPP-29.89\% }\end{array}$} & \multicolumn{3}{|c|}{$\begin{array}{c}\text { AUGUST, } 2014 \\
\text { NPP-35.74\% }\end{array}$} & \multicolumn{3}{|c|}{$\begin{array}{c}\text { MARCH, } 2015 \\
\text { NPP-27.42\% }\end{array}$} \\
\hline 1 & 200 & 26 & $13.00 \%$ & 183 & 16 & $8.74 \%$ & 114 & 10 & $8.77 \%$ & 203 & 28 & $13.79 \%$ & 150 & 13 & $8.67 \%$ \\
\hline 3 & 50 & 3 & $6.00 \%$ & 66 & 13 & $20.00 \%$ & 32 & 4 & $13.00 \%$ & 60 & 13 & $21.67 \%$ & 36 & 2 & $5.56 \%$ \\
\hline 4 & 82 & 24 & $29.27 \%$ & 76 & 9 & $11.84 \%$ & 42 & 10 & $23.81 \%$ & 82 & 18 & $21.95 \%$ & 40 & 5 & $12.50 \%$ \\
\hline 5 & 60 & 6 & $10.00 \%$ & 80 & 11 & $13.75 \%$ & 32 & 9 & $28.13 \%$ & 49 & 7 & $14.29 \%$ & 36 & 3 & $8.33 \%$ \\
\hline 8 & 3 & 1 & $33.00 \%$ & 4 & 2 & $50.00 \%$ & 1 & 0 & $0.00 \%$ & 5 & 3 & $60.00 \%$ & 1 & 1 & $100.00 \%$ \\
\hline 9 & 61 & 31 & $50.82 \%$ & 152 & 70 & $46.05 \%$ & 97 & 53 & $54.64 \%$ & 50 & 21 & $42.00 \%$ & 127 & 64 & $50.39 \%$ \\
\hline 10 & 25 & 0 & $0.00 \%$ & 25 & 0 & $0.00 \%$ & 18 & 2 & $11.11 \%$ & 27 & 2 & $7.41 \%$ & 23 & 3 & $13.04 \%$ \\
\hline 11 & 151 & 27 & $17.88 \%$ & 162 & 15 & $9.26 \%$ & 135 & 24 & $17.78 \%$ & 175 & 14 & $8.00 \%$ & 133 & 14 & $10.53 \%$ \\
\hline 12 & 58 & 7 & $12.07 \%$ & 49 & 0 & $0.00 \%$ & 55 & 11 & $20.00 \%$ & 75 & 2 & $2.67 \%$ & 48 & 6 & $12.50 \%$ \\
\hline
\end{tabular}




\begin{tabular}{|c|c|c|c|c|c|c|c|c|c|c|c|c|c|c|c|c|}
\hline \multirow{2}{*}{ TEIs } & \multicolumn{3}{|c|}{$\begin{array}{c}\text { SEPTEMBER, } 2015 \\
\text { NPP-31.36\% }\end{array}$} & \multicolumn{3}{|c|}{$\begin{array}{c}\text { MARCH, } 2016 \\
\text { NPP-28.39\% }\end{array}$} & \multicolumn{3}{|c|}{$\begin{array}{c}\text { SEPTEMBER, } 2016 \\
\text { NPP-30.18\% }\end{array}$} & \multicolumn{3}{|c|}{$\begin{array}{c}\text { MARCH, } 2017 \\
\text { NPP-10.39\% }\end{array}$} & \multicolumn{3}{|c|}{$\begin{array}{c}\text { SEPTEMBER, } 2017 \\
\text { NPP-26.33\% }\end{array}$} & \multirow{2}{*}{$\begin{array}{c}\text { TWANPPT } \\
10\end{array}$} \\
\hline & $\mathrm{T}$ & $\mathrm{P}$ & $\%$ & $\mathrm{~T}$ & $\mathrm{P}$ & $\%$ & $\mathrm{~T}$ & $\mathrm{P}$ & $\%$ & $\mathrm{~T}$ & $\mathrm{P}$ & $\%$ & $\mathrm{~T}$ & $\mathrm{P}$ & $\%$ & \\
\hline 1 & 151 & 30 & $19.87 \%$ & 90 & 12 & $13.33 \%$ & 151 & 46 & $30.46 \%$ & 98 & 6 & $6.12 \%$ & 136 & 31 & $22.79 \%$ & 1 \\
\hline 2 & 119 & 63 & $52.94 \%$ & 51 & 21 & $41.18 \%$ & 197 & 107 & $54.31 \%$ & 90 & 26 & $28.89 \%$ & 155 & 92 & $59.35 \%$ & 10 \\
\hline 3 & 40 & 7 & $17.50 \%$ & 20 & 3 & $15.00 \%$ & 51 & 9 & $17.65 \%$ & 33 & 1 & $3.03 \%$ & 38 & 6 & $15.79 \%$ & 0 \\
\hline 4 & 42 & 2 & $4.76 \%$ & 29 & 2 & $6.90 \%$ & 63 & 10 & $15.87 \%$ & 37 & 4 & $10.81 \%$ & 45 & 8 & $17.78 \%$ & 2 \\
\hline 5 & 42 & 6 & $14.29 \%$ & 33 & 7 & $21.21 \%$ & 52 & 11 & $21.15 \%$ & 39 & 2 & $5.13 \%$ & 42 & 4 & $9.52 \%$ & 0 \\
\hline 6 & 80 & 37 & $46.45 \%$ & 35 & 12 & $34.29 \%$ & 93 & 54 & $58.06 \%$ & 34 & 6 & $17.65 \%$ & 93 & 49 & $52.69 \%$ & 10 \\
\hline 7 & 53 & 21 & $39.62 \%$ & 27 & 11 & $40.74 \%$ & 94 & 34 & $36.17 \%$ & 59 & 13 & $22.03 \%$ & 70 & 19 & $27.14 \%$ & 6 \\
\hline 8 & 3 & 0 & $0.00 \%$ & 1 & 0 & $0.00 \%$ & 4 & 4 & $100 \%$ & 2 & 0 & $0.00 \%$ & 9 & 3 & $33.33 \%$ & 6 \\
\hline 9 & 212 & 97 & $45.75 \%$ & 166 & 94 & $56.63 \%$ & 243 & 138 & $56.79 \%$ & 186 & 53 & $28.49 \%$ & 282 & 110 & $39.01 \%$ & 10 \\
\hline 10 & 22 & 2 & $9.09 \%$ & 14 & 2 & $14.29 \%$ & 19 & 2 & $10.53 \%$ & 18 & 0 & $0.00 \%$ & 26 & 0 & $0.00 \%$ & 0 \\
\hline 11 & 139 & 21 & $15.11 \%$ & 98 & 22 & $22.45 \%$ & 127 & 28 & $22.05 \%$ & 104 & 7 & $6.73 \%$ & 115 & 18 & $15.65 \%$ & 0 \\
\hline 12 & 37 & 3 & $8.11 \%$ & 51 & 15 & $28.57 \%$ & 50 & 5 & $10.00 \%$ & 38 & 3 & $7.89 \%$ & 46 & 4 & $8.70 \%$ & 1 \\
\hline TWANPPT & & & 4 & & & 5 & & & 6 & & & 5 & & & 5 & 46 \\
\hline
\end{tabular}

Legend:T -Takers; P -Passers; TWANPPT -TEIs With Above National Passing Percentage Total

3. Policies and Practices of TEIs and their Relationship to the Performance of their Graduates

3.1. Policies and Practices of TEIs and their

Relationship to the Performance of their BEEd Graduates in the LET.

3.1.1. Performance Level of TEIs in BEEd-LET with Selective and Non-Selective Admission Policy

Table 4 shows that out of four (4) TEIs which implement a selective admission policy on their teacher education students, onlythree TEIs $(2,6, \& 8)$ have graduates who successfully passed the teachers licensure examination above the national passing rate in five consecutive years. In ten examinations during the five-year period, TEI 7 performed above the national passing rate only in January 2014, September 2015, and four examinations in 2016 and 2017. Of the eight TEIs with non-selective admission policy, six of these performed below the national passing rate in ten examinations from 2013 to 2017. The other two TEIs either performed above or below the national passing rate. The results prove that admission policy is a contributory factor towards the attainment of better performance of TEIs in the licensure examination for teachers specifically, the BEEd. On the other hand, TEIs that are non-performing or attaining below national passing rate performance in the licensure examination for teachers is caused by their open admis sion policy.

Table.4: Performance Level of TEIs in BEEd-LET with Selective and Non-Selective Admission Policy from 2013 to 2017.

\begin{tabular}{|c|c|c|c|c|c|c|c|c|c|c|}
\hline \multirow{3}{*}{ TEI Code } & \multicolumn{10}{|c|}{ LET Performance Level } \\
\hline & \multicolumn{2}{|c|}{2013} & \multicolumn{2}{|c|}{2014} & \multicolumn{2}{|c|}{2015} & \multicolumn{2}{|c|}{2016} & \multicolumn{2}{|c|}{2017} \\
\hline & Mar & Sept & Jan & Aug & Mar & Sept & Mar & Sept & Mar & Sept \\
\hline NPR (\%) & 27.7 & 31.18 & 29.89 & 35.74 & 27.42 & 31.36 & 28.39 & 30.18 & $\mathbf{1 0 . 3 9}$ & 26.33 \\
\hline $1-\mathrm{NS}$ & $\bar{B}$ & $\bar{B}$ & $\bar{B}$ & $\bar{B}$ & $\bar{B}$ & $\bar{B}$ & $\bar{B}$ & $\overline{\mathrm{W}}$ & $\bar{B}$ & $\bar{B}$ \\
\hline $2-S$ & A & A & A & A & A & A & A & A & A & A \\
\hline $3-\mathrm{NS}$ & B & B & B & B & B & B & B & B & B & B \\
\hline 4-NS & A & B & B & B & B & B & B & B & B & B \\
\hline $5-\mathrm{NS}$ & B & B & B & B & B & B & B & B & B & B \\
\hline $6-S$ & A & A & A & A & A & A & A & A & A & A \\
\hline $7-S$ & B & W & A & B & B & A & A & A & A & A \\
\hline 8-NS & A & A & B & A & A & B & B & A & B & A \\
\hline $9-\mathrm{S}$ & A & A & A & A & A & A & A & A & A & A \\
\hline $10-\mathrm{NS}$ & B & B & B & B & B & B & B & B & B & B \\
\hline $11-\mathrm{NS}$ & B & B & B & B & B & B & B & B & B & B \\
\hline $12-\mathrm{NS}$ & B & B & B & B & B & B & W & B & B & B \\
\hline TEI BNPR & 7 & 7 & 8 & 8 & 8 & 8 & 7 & 6 & 8 & 7 \\
\hline TEIWNPR & $\mathbf{0}$ & 1 & $\mathbf{0}$ & $\mathbf{0}$ & $\mathbf{0}$ & $\mathbf{0}$ & 1 & 1 & $\mathbf{0}$ & $\mathbf{0}$ \\
\hline TEI ANPR & 5 & 4 & 4 & 4 & 4 & 4 & 4 & 5 & 4 & 5 \\
\hline
\end{tabular}


Legend:

NPR-National Passing Rate

$W$-Within NPR

A-Above NPR

B-Below NPR

\subsubsection{Performance Level of TEIs in BEEd-LET with Selective and Non-Selective Retention Policy}

Table 5 shows that five (5) TEIs (2, 6, 7, 9, and 11) out of 12 implement the selective retention policy to their teacher education students in BEEd. Three of these TEIs have their graduates successfully passed the LET above the national passing rate (TEIs 2, 6, and 9). However, four (4) of the TEIs $(3,4,5$, and 10) that practiced non-selective retention performed below the national passing rate during the 10 examinations conducted from year 2013 to 2017. Also, two (2) TEIs (1 and 12) with non-selective retention policy attained below national passing rate performance nine (9) times and once with within the national passing rate performance.

Table.5: Performance Level of TEIs in BEEdLET with Selective and Non-Selective Retention Policy from 2013 to 2017

\begin{tabular}{|c|c|c|c|c|c|c|c|c|c|c|}
\hline \multirow{3}{*}{ TEI Code } & \multicolumn{10}{|c|}{ LET Performance Level } \\
\hline & \multicolumn{2}{|c|}{2013} & \multicolumn{2}{|c|}{2014} & \multicolumn{2}{|c|}{2015} & \multicolumn{2}{|c|}{2016} & \multicolumn{2}{|c|}{2017} \\
\hline & Mar & Sept & Jan & Aug & Mar & Sept & Mar & Sept & Mar & Sept \\
\hline NPR (\%) & 27.7 & 31.18 & 29.89 & 35.74 & 27.42 & 31.36 & 28.39 & 30.18 & 10.39 & 26.33 \\
\hline $1-\mathrm{NS}$ & B & B & B & B & B & B & B & W & B & B \\
\hline $2-S$ & A & A & A & A & A & A & A & A & A & A \\
\hline $3-\mathrm{NS}$ & B & B & B & B & B & B & $\mathrm{B}$ & B & B & B \\
\hline 4-NS & A & B & B & B & B & B & B & B & B & B \\
\hline $5-\mathrm{NS}$ & B & B & B & B & B & B & B & B & B & B \\
\hline 6-S & A & A & A & A & A & A & A & A & A & A \\
\hline 7-S & B & W & A & B & B & A & A & A & A & A \\
\hline 8-NS & A & A & B & A & A & B & B & A & B & A \\
\hline 9-S & A & A & A & A & A & A & A & A & A & A \\
\hline 10-NS & B & B & B & B & B & B & B & B & B & B \\
\hline $11-\mathrm{S}$ & B & B & B & B & B & B & B & B & B & B \\
\hline $12-\mathrm{Ns}$ & B & B & B & B & B & B & W & B & B & B \\
\hline TEI BNPR & 7 & 7 & 8 & 8 & 8 & 8 & 7 & 6 & 8 & 7 \\
\hline TEIWNPR & $\mathbf{0}$ & 1 & $\mathbf{0}$ & $\mathbf{0}$ & $\mathbf{0}$ & $\mathbf{0}$ & 1 & 1 & $\mathbf{0}$ & $\mathbf{0}$ \\
\hline TEI ANPR & 5 & 4 & 4 & 4 & 4 & 4 & 4 & 5 & 4 & 5 \\
\hline
\end{tabular}

Legend:

NPR-National Passing Rate

W-Within NPR

A-Above NPR

$\boldsymbol{B}-$ Below NPR

Apparently, TEI 11 had below the national passing rate performance from years 2013 to 2017 examinations despite of practicing a selective retention policy. Likewise, TEI 8 had 6 out of $12(50 \%)$ performance despite practicing a non-selective retention policy to its students.

The findings imply that retention policy is important in the acade mic institutions considering that TEIs that has a selective retention policy performed better in the BEEd-LET as compared to TEIs with the non-selective retention policy.
4. Practices Implemented by the Respondent Schools to Improve their LET Performance

Table 6 presents the practices of respondent Teacher Education Institutions being implemented to improve the LET performance of their graduates. As shown in the table, all the $12 \mathrm{TEI}$ 's implement the practices in ensuring the success of their graduates in the LET; however, it was conducted/implemented in different degrees. Based on the interviews and data gathered using a survey questionnaire, the following results are hereby accounted:

\subsection{Inculcate to Students that their Course has a LET}


All the 12 TEls of Nueva Ecija believe and apply this practice. During the enrollment, registration adviser gives advice to the applicant that the program to be enrolled in is a "board" course. The importance and rudiments of the course are being highlighted during the interview of the applicant that the applicant may grasp and understand fully. Therefore, the course should be handled with deep seriousness in their studies, strong dedication or hard work, determination to finish the program until graduation and pass the licensure examination for and in behalf of the institution.

Respondents during the interview said that from first year to fourth year college, they did not stop reminding their students that their course is a board course.

\subsection{Term Examinations and Ans wer Sheet Patterned from LET}

In this practice, TEls 2, 6, and 9 led in doing such as compared to the rest of TEIs. The aforesaid three (3) TEIs develop examinations similar to that of the LET in relation to the concept of higher order thinking skills, type of examination, technical format. Further, examination includes questions gathered from a series of LET through TEIs' graduates who already passed the LET. In connection, term examinations were based on PRC based syllabi. Hence, teacher education graduates are being trained to answer questions that are somehow modeled to LET.

\section{Table.6: Practices of Respondent TEIs}

\begin{tabular}{|c|c|c|}
\hline Practices & f & $\%$ \\
\hline $\begin{array}{l}\text { 1. Inculcate to students that their course has a } \\
\text { LET. }\end{array}$ & 12 & 100 \\
\hline $\begin{array}{l}\text { 2. Term examinations and answer sheet patterned } \\
\text { from the LET. }\end{array}$ & 12 & 100 \\
\hline 3. Counseling and monitoring of students. & 6 & 50 \\
\hline $\begin{array}{l}\text { 4. Conduct of informal review or course audit. } \\
\text { 5. Identification of review centers specialized in } \\
\text { LET. }\end{array}$ & 5 & $\begin{array}{r}41.67 \\
100\end{array}$ \\
\hline
\end{tabular}

However, interview with deans/heads and teachers resounded that it is not only the type and content of the exam that matters but even the manner of how the students take the examination. Term examinations are admin istered with prescribed time in order to train students to handle their examinations without being affected by time pressure. Also, teacher respondents are being trained to analyze questions; even the technique of shading their answers is being practiced correctly. Likewise, the design of the answer sheet is also patterned to LET answer sheet.
Hence, the practice prepares teacher education graduates to handle the LET in the future. It further inculcates and accustoms TEIs' teacher education students which reduce fear, anxiety, and stress associated when taking the LET.

\subsection{Counseling and Monitoring of Students}

The 12 TEIs mentioned that they conduct periodic counseling and monitoring of students' behavior and performance to see the emotional and psychological readiness of students in connection to LET after graduating their course. Students with difficulties in their studies, based on their term examination performance, are being subjected for counseling. However, during the examination of guidance offices' records of TEIs, only six (6) TEIs do have a program calendar of evaluation and assessment of their students in relation to the academic performances of teacher education students while the rest of the TEIs have no proof of records to show.

Hence, the findings led the researcher to assume that half of the TEIs (TEIs 1, 3, 6, 7, 9, and 11) do really provide the necessary extra service (guidance and counseling) to their students beyond academic matters while half TEIs did not. Further, it signifies that half of the TEIs understand the significance of guidance and counseling towards the attainment of better academic and LET performance.

\subsection{Conduct of Informal Review or Course Audit}

Based on the interview with teacher respondents, it was observed that only five (5) TEIs practice the conduct of informal review or course audit. In reiteration, also, during the interview with deans/heads and teachers from five (5) TEIs, they totally ad mitted that they provided informal LET preparation measures for the benefit of their graduates such as but not limited to the following: conducting series of mock board examinations while on OJT to those willing students only, conducting series of mock board examinations after graduation before the LET on a voluntary basis, inviting alu mni fresh passers with excellent LET ratings to conduct lectures and share their LET experiences on a free basis, teachers voluntarily deliver free lectures, and monitor graduates on their performance in the review centers. Ironically, during the course of group discussion with six (6) teacher education graduates who just passed the LET, they said that their school required them to pass assessment exams prepared by their college before they were allowed to graduate; failed students did not graduate until they waited for the next semester. Unknown 
to them that time that the assessment exams imposed upon them were without any legal basis. However, they frankly said, "Pero tama langsiguro sir yongginawanila (dean and teachers) saamin (taking the assessment exams), kasiyong batch namin ay maramingnakapasa. Bakapaghindinilaginawaiyon

$e$ bakamasmaramibagsaksaamin." The result of the interview implies that teacher education students value that efforts of their deans/heads and teachers. Further, informal review lectures serve the interests of teacher education students especially in relation passing the LET.

\subsection{Identification of Review Centers Specialized in LET}

All 12 TEIs practice the identification of accredited review centers in the province that specialized in LET and entered into a partnership. Said practice is of great help in guiding the students enroll in a quality review center. However, deans/heads and teachers of respondent TEIs observed that their graduates prefer to enroll in review centers mostly based in Manila and Baguio cities. The distance caused difficulty on the teachers to visit, monitor, and supervise their graduates. Notably, TEI 6, the only institution among the 12 TEIs in Nueva Ecija that performed consistently in the BEEd LET performance rating, it adopted two sessions of review. Firstly, an informal in-house that is being done on the $1^{\text {st }}$ semester of $4^{\text {th }}$ year students; and secondly, one with review centers after graduation.

Therefore, the practice of TEI 6 proved that their method towards improving the LET performance of their graduates in BEEd LET as well. It signifies that guiding the teacher education graduates in finding competent review centers to which they could enroll matters most.
The finding of the study is consistent with the study of [24] who reiterated that education graduates before taking the licensure examination for teachers should be compelled to attend review classes in preparation for LET. He stressed the fact that Graduate-related factors like Teaching Aptitude Test (TAT) and attendance in LET review classes are good predictors of performance in LET. In sum, the findings of the study suggest that TEIs are aware that good performance in the BEEd-LET is important. Hence, TEIs performed the above-mentioned practices in order for them to obtain an above the national passing rate performance every BEEd-LET. Otherwise, the CHEd would is sue a warning in case TEIs performed below the national passing rate performance in 3 to 5 cons ecutive examinations.

5. Relationship of the Schools' Policies in Terms of Admission, Retention and LET Preparation in the Performance of Education Graduates in their BEEdLET.

\subsubsection{Admission and Performance Level}

Table 7 shows that admission policy is significant to the performance level of TEIs in most (9 out of 10) of the examinations except during March 2013 licensure examination for teachers at .05 level of significance. This implies that admission policy is a contributory factor towards the attainment of better LET performance. Also, it signifies that an above national passing rate performance in the BEEd-LET is possible through espousal of admission policy by the TEIs. Contrariwise, TEIs which do not have admission policy or with admission policy but not being implemented would achieve an undesirable performance in the licensure examination for teachers.

Table.7: Admission and Performance Level of TEIs (BEEd)

\begin{tabular}{|c|c|c|c|}
\hline Date of Exam & $\begin{array}{c}\text { Pearson chi square } \\
\text { value }\end{array}$ & $p$ value & Remarks \\
\hline 2013 March & 2.713 & 0.098 & Not significant \\
\hline 2013 Sept & 8.625 & 0.013 & Significant \\
\hline 2014 Jan & 12.000 & 0.001 & Significant \\
\hline 2014 Aug & 4.688 & 0.030 & Significant \\
\hline 2015 March & 4.688 & 0.030 & Significant \\
\hline 2015 Sept & 8.400 & 0.004 & Significant \\
\hline 2016 March & 12.000 & 0.001 & Significant \\
\hline 2016 Sept & 12.000 & 0.002 & Significant \\
\hline 2017 March & 12.000 & 0.002 & Significant \\
\hline 2017 Sept & 12.000 & 0.002 & Significant \\
\hline
\end{tabular}

Alpha $=. \overline{05}$

5.1.2. Retention and Performance Level 
Table 8 shows that most of the examinations proved that retention has policy has a significant relationship on the performance of TEIs in LET at .05 level of significance. It implies that observance of retention policy has something to share on the attainment of better LET performance.
Data further displays that March and September 2016, as well as March 2017 examinations, showed a not significant result at .05 level of significance. It implies that retention policy did not show positive relationship on the national passing rate performance of TEIs during the aforesaid examinations.

Table.8: Retention and Performance Level of TEIs (BEEd)

\begin{tabular}{lccc}
\hline \multicolumn{1}{c}{ Date of Exam } & Pearson chi square value & p value & Remarks \\
\hline 2013 March & 12.000 & 0.002 & Significant \\
2013 Sept & 8.571 & 0.014 & Significant \\
2014 Jan & 5.182 & 0.023 & Significant \\
2014 Aug & 5.600 & 0.018 & Significant \\
2015 March & 8.400 & 0.004 & Significant \\
2015 Sept & 5.182 & 0.023 & Significant \\
2016 March & 2.713 & 0.098 & Not Significant \\
2016 Sept & 2.743 & 0.098 & Not Significant \\
2017 March & 2.743 & 0.098 & Not Significant \\
2017 Sept & 5.182 & 0.023 & Significant \\
\hline
\end{tabular}

Alpha $=.05$

\section{CONCLUSIONS AND RECOMMENDATIONS}

Based on the findings of the study, the following conclusions were drawn, to wit:

1. TEIs are cognizant that admission, retention, and LET preparation policies are important academic guidelines or procedures in every institution. Equally, TEIs are mindful that the aforesaid academic policies are $\mathrm{v}$ ital means to establish and maintain quality instruction to BEEd students. 2. Most TEIs failed to address their academic problems considering that their BEEd LET results were below the national passing rate performance during 10 consecutive examinations from years 2013-2017. Also, the Commission on Higher Education failed to observe or impose its policies concerning the persistent below national passing rate performance of TEIs in BEEd LET result.

3. TEIs' admission, retention, and LET preparation policies are big contributory factors towards a healthier LET performance for BEEd. Hence, admission, retention, and LET preparation policies used by TEIs for BEEd program is not applicable to BSEd program.

4. TEIs recognize the importance of achieving BEEd LET result that is above the national passing rate through the various practices they implement to improve the performance of their graduates in the LET. Similarly, TEIs are aware of the possible legal and business consequences in case they failed in every examination. Lastly, TEIs are mindful that LET performance of their graduates is a measure or indicator of quality academic practices and processes.

Based on the findings and conclusions, the following are offered:

\section{Implementation of Academic Policies}

School policies (admission and retention) shall be strictly observed with consistency in the implementation. Though education is a business, TEIs shall not relax their academic policies just to maintain or increase the quantity of students. TEIs shall focus on the quality of students, not on the quantity.

\section{Creation of Distinct Academic Policies}

TEIs shall establish and implement an admission, retention, and LET preparation policies that are unique and applicable to each program. Hence, there shall be different policy (admission, retention, and LET preparation) for BEEd and for BSEd in order to address the individual concerns of both programs.

\section{Regular Revisiting of Curricula}

TEIs shall set a regular period (every 3 or 5 years) of revisiting, evaluating, and ass essing the curriculum for BEEd in order to ensure the updating of subjects being offered for both programs. Through this, TEIs are given the opportunity to improve the curricula for BEEd based on the boundaries set by CHEd and PRC for LET purposes. Also, regular revisiting on the curricula of both programs is a chance for TEIs to set their course offerings parallel to the needs of various institution (clienteles) in the community. 


\section{Institutionalization of LET Preparation Programs}

TEIs shall revisit and enhance their respective curriculum in order to ensure its appropriateness and completeness. TEIs curriculum shall be enhanced most importantly on the inclusion of Integrated Review, Course Audit or programs analogous to it with special consideration on the guidelines and policies set by the Commission of Higher Education and national laws. With this, informal review or course audit would be formalized and would become an integral part of academic instruction of which no teacher education student would escape. Further, it serves as intervention measures against possible below LET performance.

\section{Retooling of BEEdTeachers}

TEIs shall continue to enhance the competencies of their Education teachers. Teachers must be trained with proper review techniques to be very useful and helpful to their students who will take the board exam [25]. Likewise, they should be innovative in providing meaningful, enjoyable and engaging test experience that will enhance their learners' analytical skills in situational settings by solving both complex and simple problems and making accurate decisions given available information [26].

\section{ACKNOWLEDGEMENTS}

I a mvery grateful to Dr. Lily G. Salangsang in checking the statistical aspect of my research. Likewise, thanks are due to Dr. Jesster P. Eduardo and Dr.GenerS. Subiafor editing and enhancing the content of my paper. Also, they both worked for the publication of this research.

\section{REFERENCES}

[1] Presidential Communications Office. (13 June 2018). President Duterte commits to provide quality and affordable education to all. Retrieved from https://pcoo.gov.ph/news releases/ president-dutertecommits-to-provide-quality-and-affordable education-to-all/. Retrieved: January 10, 2019.

[2] Mandela, Nelson. (1990). Speech, Madison Park High School, 23 June 1990.

[3] Memorandum Order (CMO) No.30 series of 2004. Revised Policies and Standards for Undergraduate Teacher Education Curriculum.

[4] Gana, Remoroza, Dela Cruz, and Tesoro. (March, 2014). The performance of FEU pre-service SPEd in id-formulated comprehensive examination and its influence on the licensure examination for teachers. Far Eastern University-Manila.Institute of Education Retrieved

from https://www.slideshare.net/stephaniegana1/the-

performance-of-feu-pre-service-sped-teachers-inieformu lated-comprehensive-examination-and-itsinfluence.Retrieved: January 10, 2019.

[5] Tan, W.S., Almerez, A.U., Pardillo, A., Batulan, S.S., Gonzales, J., Cal, C.I., Labang, J. (2015). Trend of customs licensure examination of the Philippines. Educational Measurement and Evaluation Review, 6, 11-22.

[6] Kuh, G. (2007). What students' engagement data tell us about college readiness? Peer Review. Indiana, USA: Indiana University Press, p. 1, 2007.

[7] Ong, M. B. \&Palompon, D. R. (2012).Predictors of nurses' licensure examination performance of graduates in Cebu Normal University, Philippines.Asian Journal of Health, Vol. 2, p. 134, 2012.

[8] Hilario, I. (2000). Factors influencing the licensure examination performance of teacher education institutions in the Cordillera Administrative Region.Unpublished Doctoral Dissertation.St. Louise University, Baguio City.

[9] Faltado III, R. E. (2013). Correlates of performance in the licensure examination of selected public and private teacher education institutions.Unpublished Doctoral Dissertation. University of Rizal System, Cainta, Rizal, 2013

[10] Antiojo, L.P. (2017). Performance of education graduates in the licensure examination for teachers (LET). PEOPLE: International Journal of Social Sciences, 3(2), 1363-1384.

[11] Aquino, A., \&Balilla, L. (2015). Pre - service teachers' licensure examination plans and content knowledge. Asia Pacific Journal of Education, Arts and Sciences, 2(2).

[12] Philippine Journal of Education.2010.

[13] CHED en BANC Resolution No.168-2012.

[14] Eduardo, J. (2018). Indigenous Peoples' Rights Act (IPRA) of 1997: A Standpoint from Selected Higher Education Institutions in Nueva EcijaAfter 20 Years. Journal of Progressive Research in Social Sciences, 8(1), 595-613. Retrieved from http://www.scitecres earch.com/journals/index.php/jprs s/article/view/1547

[15] Calderon, J. F. (1993). Textbook: method of research and thesis writing. CachoHermanos, Inc. Pines cor., Union Sts. Mandaluyong City, Philippines:

[16] Jesster P. Eduardo, Arneil G. Gabriel Assessing the Leadership Skills of the Chiefs of Police in the Towns 
of Nueva Ecija, Philippines: A Dichotomy between

Managerial Competence and Decision Making Ability

Open Journal of Leadership, 2017 Vol.6 No.4, December 2017

[17] Devi, P.S. (2017).Research methodology: a handbook for beginners. Notion Press. Ethiopia

[18] Guan zon, D.T.P. (2013). Philippine Normal University admission test and college point average as predictors of licensure examination for teachers.

[19] Pascua, J. and Navalta, J. (2011).Determinants of L.E.T. performance of the teacher education graduates in a state university. JPAIR Multid isciplinary Journal, Volume $6, \quad$ doi: http://dx.doi.org/10.7719/jpair.v 6i1.138.

[20] Hena, R. H., Ballado, R.S., Dalucapas, C., Ubane, S. and Bashierto, R. (2014). Variates of the performance of teacher education graduates in the licensure examination for teachers (LET). International Journal of Interdisciplinary Research and Innovations, 2(4): 157-163.

[21] Figuerres, O. (2010). An Analysis of the Performance of the University of Northern Philippines in the Licensure Examination for Teachers. International Journal of Educational Research and Technology. Retrieved from www.soeagra.Original Article com/ijert/ijert.htm. January 9, 2019.

[22] Tamayo, A.M., Bernardo, G., Eguia, R. (2014).Readiness for the licensure exam of the engineering students.Retrieved from ttps://goo.gl/LHhXUn.Retrieved: January 10, 2019.

[23] Pachejo, S. \&A llaga, W. (2013).Academic predictors of the licensure examination for teachers' performance of the Rizal Technological University teacher education graduates. International Journal of Educational Research and Technology, 4(4), 31-40.

[24] Visco, D.A. (2015) Determinants of Performance in the licensure examination for teachers LET of ABRA State Institute of Sciences and Technology.

[25] Subia, G.S. (2018).Comprehensible Technique in Solving Consecutive Number Problems in Algebra. Journal of Applied Mathematics and Physics, 6,447457.https://doi.org/10.4236/jamp.2018.63041

[26] Subia, Gener S.(2018).Think Like My Teacher (TLMT): a New Method in Assessing Millennial Learners. International Journal of Arts Humanities and Social Sciences. Volume 3 Issue 1 \| January 2018.www.ijahss.com 